\title{
Effect of selenium-vitamin $E$ injection in selenium-deficient dairy goats and kids on the Mexican plateau
}

[Efeito do selênio e da vitamina E sobre a produtividade de cabras e cabritos no México]

\author{
J.E. Ramírez-Bribiesca ${ }^{1}$, J.L. Tórtora ${ }^{2}$, M. Huerta ${ }^{3}$, L.M. Hernández ${ }^{4}$, R. López ${ }^{2}$, M.M. Crosby ${ }^{1}$ \\ ${ }^{1}$ Programa de Ganadería - Colegio de Posgraduados \\ km 36.5 Carr. México-Texcoco, C.P. 56230 \\ Montecillo-Texcoco, Edo.de México. México \\ ${ }^{2}$ Universidad Nacional Autónoma de México - FES-C \\ ${ }^{3}$ Universidad Autónoma de Chapingo \\ ${ }^{4}$ Universidad Autónoma Metropolitana-Iztapalapa - DCByS
}

\begin{abstract}
Three experiments were carried out to determine the optimum selenium-vitamin E injection level to maintain acceptable blood selenium (Se) status of does and kids, as well as to determine the relation of that status to mortality rates in kids. In experiment 1, 238 goats were assigned to one of three groups during the mating period: A1-control, A2- $0.06 \mathrm{mgSe}+0.8 \mathrm{IU}$ vitE $/ \mathrm{kgBW}$ and $\mathrm{A} 3-0.125 \mathrm{mgSe}+1.7 \mathrm{IU}$ vitE $/ \mathrm{kgBW}$. No differences $(\mathrm{P}>.05)$ for fertility and prolificacy were observed among the groups. Blood Se concentration did not differ among Se-vit E groups and control group before injection, and both groups showed Se deficient condition. There was a trend $(\mathrm{P}<.05,32 \%)$ to increase Se blood level 60 days post-treatment, but difference was not observed between $\mathrm{A} 2$ and control groups, while difference $(\mathrm{P}<.05 ; 103 \%)$ was observed between $\mathrm{A} 1$ and A2 groups vs high Se injection (A3 group). In experiment 2, 48 goats were divided into four groups: B1- control, B2- $0.125 \mathrm{mgSe}+1.7 \mathrm{IU}$ vitE $/ \mathrm{kgBW}, \mathrm{B} 3-0.25 \mathrm{mgSe}+3.4 \mathrm{IU}$ vitE $/ \mathrm{kgBW}$ and B4- $0.31 \mathrm{mgSe}+4.2 \mathrm{IU}$ vitE $/ \mathrm{kgBW}$. The B4 group reached the highest concentration at the third month after injection $(0.11 \mathrm{ppm})$, then started to decline after 100 days, reaching a value slightly higher than $\mathrm{B} 2$ and $\mathrm{B} 3$ on the $135^{\text {th }}$ day of pregnancy. Results of $\mathrm{B} 2$ and $\mathrm{B} 3$ groups were slightly higher that those of $\mathrm{B} 1(\mathrm{P}<0.05)$. In experiment 3,194 kids ( 3 to 7 days postpartum) born from Se-deficient goats were used to compare the effectiveness of Se injection. They were divided into three groups: $\mathrm{C} 1$ - control, $\mathrm{C} 2-0.3 \mathrm{mgSe}+4.2 \mathrm{IU}$ vit $\mathrm{E} / \mathrm{kg} \mathrm{BW}$ and $\mathrm{C} 3-0.6 \mathrm{mgSe}+8.4 \mathrm{IU}$ vit E/ $\mathrm{kg}$ BW. C1 showed the highest percentage of mortality $(60 \%)$ as compared to treated Se groups, that scored equal percentage of deaths ( $22 \%$ averaged). The concentration of Se in blood, on day $20^{\text {th }}$ after the onset of the treatment rapidly increased, according with level of Se injection. The $0.3 \mathrm{mgSe} / \mathrm{kgBW}$ Se injection increased the blood Se concentration in pregnant goats and it was effective to prevent white muscle disease lesions, besides enhancing the survival of kids until weaning.
\end{abstract}

Keywords: goat, selenium, vitamin E, México

\section{RESUMO}

Foram conduzidos três experimentos para determinar a quantidade ótima da injeção de selênio-vitamina $E$ (Se-vit E) para manter o nivel aceitável do status de selênio no sangue de cabras e cabritos e determinar essa relação com o status sobre a taxa de mortalidade de cabritos. No primeiro experimento, 238 cabras foram usados em um dos três grupos durante o perído do acasalamento: A1- controle, A2- 0,06mgSe+0,8UI vit E/kg de peso-vivo e A3- 0,125mgSe+1,7UI vitE/kg de peso-vivo. Não houve diferenças $(P>0,05)$ entre os grupos para fertilidade e prolificidade. A concentração de Se no sangue não foi diferente entre os grupos que

Recebido para publicação em 28 de julho de 2003

Recebido para publicação, após modificações, em 4 de fevereiro de 2004

E-mail: efrenrb@colpos.mx 


\section{Ramírez-Bribiesca et al.}

receberam Se-vit E e o controle antes da injeção e ambos os grupos mostravam deficiência de Se. Sessenta dias pós-tratamento houve tendência $(P<0,05 ; 32 \%)$ de aumentar o nível de Se no sangue e não houve diferença entre os grupos A2 e controle. Houve diferença significativa $(P<0,05 ; 103 \%)$ entre os grupos Ale A2 e o grupo A3. No segundo experimento, 48 cabras foram divididas em quatro grupos: B1-controle, B20,125mgSe+1,7UI vitE/kg de peso-vivo, B3- 0,25mgSe+3,4UI vitE/kg de peso-vivo e B4- 0,31 mgSe+4,2UI vitE/kg de peso-vivo. O grupo B4 alcançou a concentração mais alta no terceiro mês depois da injeção $(0,11$ ppm) e diminuiu depois de 100 dias, quando o valor foi apenas ligeiramente maior que os valores dos grupos B2 e B3, aos 135 dias da gestação. Os resultados dos grupos B2 e B3 foram ligeiramente mais altos que os do grupo $B 1$ ( $P<0,05)$. No terceiro experimento, 194 cabritos ( 3 a 7 dias de idade), nascidos de cabras deficientes em Se, foram usados para comparar a efetividade da injeção de Se. Foram divididos em três grupos: C1-controle, C2- 0,3mgSe+4,2UI vit E/kg de peso-vivo e C3- 0,6mgSe+8,4UI vit E/kg de peso-vivo. A porcentagem de mortalidade foi mais alta em C1 (60\%) e mais baixa nos grupos tratados com Se (22\%). A concentração de Se no sangue no $20^{\circ}$ após o início do tratamento aumentou rapidamente, de acordo com o nível de injeção de Se. A injeção com $0,3 \mathrm{mgSe} / \mathrm{kg}$ de peso-vivo aumentou a concentração de Se no sangue em cabras gestantes e a dose foi efetiva para prevenir a doença de músculo branco e aumentar a sobrevivência dos cabritos até o desmame.

Palavras-chave: selênio, vitamina E, caprino, México

\section{INTRODUCTION}

Selenium (Se) has a biological function related to vitamin $\mathrm{E}$ in that $\mathrm{Se}$ is a essential component of glutathion peroxidase, an enzyme involved in detoxification of hydrogen peroxide and lipid hydroperoxides. The vit. E requirement may therefore be defined as the amount required to prevent peroxidation in the particular subcellular membrane which is most susceptible to peroxidation. Moreover, Se is a component of selenoproteins and is involved in immune and neuropsychological function in the nutrition of animals (Meschy, 2000). Se deficiency plays a role in numerous economically important livestock diseases, problems that include impared fertility, abortion, retained placenta and neonatal weakness (McDowell et al., 1996). In the plateau of Mexico, crops and forages grown in regions with $\mathrm{Se}-$ deficient soils are deficient in Se, which was recognized by the farming community as a particular problem. The clinical symptoms of white muscle disease (WMD) are usually observed in kids (Ramírez et al., 2001a; Ramirezet al., 2001b). A survey of veterinarians practicing in Mexico revealed that Se-vitE administration in goats has been extrapolated from cattle, and in the majority of these cases, the decision to inject selenium was not based on verification of the Se status of the goats.
Several studies have determined that injections of supplemental Se solution increased serum and tissue concentrations of the element, and serum or plasma selenium concentration provide a good indication of Se status in ruminants (Pastrana et al., 1991; Andrés et al., 1996). Administration of Se improves daily weight gain in lambs (Gabryszuk and Klewiec, 2002), and reproductive performance in ewes. However, little information is available for goats (Meschy, 2000). The objective of these experiments was to determine the effect of differents levels of Se/vitamin E injections on the productivity of pregnant goats and prophylaxis of WMD mortality in kids.

\section{MATERIAL AND METHODS}

Three experiments were carried out in a traditional flock in the Ixtenco region of the State of Tlaxcala, Mexico. Ixtenco is a region that is located on the Malintzi mountain area over $2,600 \mathrm{~m}$ above sea level, with mean temperature of $11^{\circ} \mathrm{C}$ and $624 \mathrm{~mm}$ annual rainfall. Goat flocks studied had native breeds with some characteristics of Alpine, Nubian and Saanen. The animals are kept in open corrals at night and in goat shed during the rainy season. Feeding goats consisted of grazing natural vegetation for $8 \mathrm{~h}$ daily and occasional supplementation with common salt. 
Selenium deficiency in goats and kids of this region is due to deficient concentrations of this element in the soil and forages (Ramirez-Bribiesca et al., 2001b). However, these native does and kids were used to compare the effectiveness of Se supplement injections. Injected $\mathrm{Se} / \mathrm{Vit} \mathrm{E}$ was a MU-SE® ${ }^{1}$, which contains $5 \mathrm{mgSe}$ and $68 \mathrm{IU}$ Vitamin $\mathrm{E} \mathrm{ml}^{-1}$.

\section{Experiment 1}

The experiment started in autumn with the natural mating period. Mature does, weighing approximately 36 to $45 \mathrm{~kg}$ and $24-36$ months old (judged on the basis of permanent incisor dentition) were exposed to bucks for the first time during November and December. Bucks were fitted with marking crayons to indicate when a doe had been mounted and the flock was checked daily to detect mounted does. When the markings were observed, the does were identified by ear tags, recorded and assigned randomly to one of the following three treatment groups: A1- control, that received a subcutaneous saline solution injection $(\mathrm{n}=79)$, A2that received $0.06 \mathrm{mgSe}+0.8 \mathrm{IU}$ vitamin $\mathrm{E} / \mathrm{kgBW}$ $(\mathrm{n}=79)$ and A3- received $0.125 \mathrm{mgSe}+1.7 \mathrm{IU}$ vitamin $\mathrm{E} / \mathrm{kgBW}(\mathrm{n}=80)$. Both dosages were injected according to the laboratory recommendation ${ }^{1}$.

All does in the A2 and A3 groups received a subcutaneous injection of sodium selenite and vitamin with different volumes to adjust BW doses. Before each injection, blood samples were collected by jugular venipucture at random from 16 goats in each group and 60 days after the start of the experiment blood samples were obtained from the same animals previously confirmed the gestation by ultrasound. Fertility ((number of does to give birth / number of does that were mated by the buck) X 100) and prolificacy ((number of kids born / number of does to gave birth) X 100) were determined in all animals of each group.

\section{Experiment 2}

The experiment was carried out with does of control group (A1) used in experiment 1, and began 10 months after the first experiment ended. The experiment was designed to extend the previous observations and delineate the better

${ }^{1}$ MU-SE® - Schering Corporation, USA blood profiles of Se in pregnant does. All remaining ovulating does were exposed to bucks under natural conditions, the same as in experiment 1. Bucks were fitted with marking crayons to indicate when a doe was mounted. Does in each group were pregnancy tested using ultrasound (2 months) and all nonpregnant does were removed from the study. At that time, does were randomly allowed divided to four groups. Does in each group were randomly assigned to the following treatments (12 does per treatment - subcutaneous doses): B1-control with saline solution, B2received $0.125 \mathrm{mgSe}+1.7 \mathrm{IU}$ vitE $/ \mathrm{kgBW}$, B3received $0.25 \mathrm{mgSe}+3.4 \mathrm{IU}$ vitE/ $\mathrm{kgBW}$ and $\mathrm{B} 4-$ received $0.31 \mathrm{mgSe}+4.2 \mathrm{IU}$ vitE $/ \mathrm{kgBW}$. Blood samples were recorded immediately before injection, and on days 20, 60, 90 and 135 after injection, corresponding approximately to the gestation days in goats.

\section{Experiment 3}

A total of 196 kids born from Se-deficient does, and does not supplemented with selenium sources, from a commercial flock from the same region of the state of Tlaxcala, were used to compare the effectiveness of selenium and vitamin $\mathrm{E}$ injection. The experiment was carried out during the kidding season (March-April). The kids (3 to 7 days old) were eartagged and randomly divided into three groups: $\mathrm{C} 1$-control $(\mathrm{n}=40)$ that received a $0.5 \mathrm{ml}$ subcutaneous injection of saline solution, $\mathrm{C} 2-(\mathrm{n}=$ 78 ) that received $0.3 \mathrm{mgSe}$ and $4.2 \mathrm{IU}$ vit $\mathrm{E} / \mathrm{kg} \mathrm{BW}$ and $\mathrm{C} 3(\mathrm{n}=78)$ that received $0.6 \mathrm{mgSe}$ and $8.4 \mathrm{IU}$ vit $\mathrm{E} / \mathrm{kg} \mathrm{BW}$.

The mortality was recorded for all three treatment groups until 60 days of age, the generally weaning age in Mexico. Blood samples were collected by jugular venipuncture from 16 kids per group immediately before treatment and at 20 days after the start of treatment.

Blood was drawn from the jugular vein using with evacuated glass EDTA anticoagulant tubes ${ }^{2}$. The blood samples were frozen at $-80^{\circ} \mathrm{C}$ until assayed for selenium. Plasma selenium concentration was analyzed by DAN (2,3-diaminonaphthalene)fluorescence spectrophotometer (Whetter and Ullrey, 1978).

\footnotetext{
${ }^{2}$ SST Vacutainer, Becton-Dickinson, Rutherford, New Jersey, USA
} 


\section{Ramírez-Bribiesca et al.}

The differences between injected groups in goats of experiment 1 and kids of experiment 3 were estimated using the following model:

$\mathrm{Yij}=\mu+\mathrm{a}_{\mathrm{i}}+\mathrm{e}_{\mathrm{ij}}$, where

$\mu$ is the overall mean, $a_{i}$ the effect of ith injection Se group, and $e_{i j}$ the random error.

The differences between injected groups in goats of experiment 2 were estimated using the following model:

$\mathrm{Yij}=\mu+\mathrm{a}_{\mathrm{i}}+\mathrm{b}_{\mathrm{j}}+(\mathrm{ab})_{\mathrm{ij}}+\mathrm{e}_{\mathrm{ijk}}$, where

$\mu$ is the overall mean, $a_{i}$ the effect of ith injection Se group $\left({ }_{I}=1-4\right), b_{j}$ the effect of $j$ th gestation days $(j=1-4),(a b)_{i j}$ the interaction of $i$ th injection dosis $\mathrm{x} j$ th gestation days, and $\mathrm{e}_{i j k}$ the random error.

Reproductive rate and mortality percentage were examined by Chi-square test (Steel and Torrie, 1980). Differences in blood Se concentrations were analyzed by GLM procedure of SAS (User's..., 1990), and mean were separated using Duncan's multiple-range tests when ANOVA indicated a significant $(\mathrm{P}<.05)$ treatment response (Steel and Torrie, 1980).

\section{RESULTS AND DISCUSSION}

\section{Experiment 1}

Fertility and prolificacy did not differ among groups (Table 1). These observations demonstrated that Se-vit $\mathrm{E}$ injections did not affect the reproductive indexes. Fertility percentage was close to that obtained under optimal practical conditions. Basically, the flock had a history of good fertility. In contrast with the results obtained in the present study, Anke (1987) observed a decrease of fertility percentage (93 vs 64\%) in Sedeficient goats. Furthermore, a positive effect of Se-vit E on fertility and prolificacy was observed in 3-year-old ewes with two injections $(2.1 \mathrm{mg}$ of $\mathrm{Se} /$ injection) before mating and lambing. However, the injection of Se plus vit E did not increase the reproduction and performance in younger ewes (Gabryszuk and Klewiec, 2002). The reasons of these discrepancies could be related to the level of $\mathrm{Se}$, interaction of Se-vit $\mathrm{E}$, and other nutrition factors as protein, energy, $\mathrm{Ca}, \mathrm{Mg}$ and $\mathrm{P}$ intake, that might also influence reproduction rates.

Table 1. Selenium content of blood samples and reproductive rate of does subcutaneously injected with selenium-vitamin E

\begin{tabular}{lccc} 
& \multicolumn{3}{c}{ Treatment groups } \\
\cline { 2 - 4 } & $\mathrm{A} 1$ & $\mathrm{~A} 2$ & $\mathrm{~A} 3$ \\
\cline { 2 - 4 } & Mean \pm SD & Mean \pm SD & Mean \pm SD \\
\hline Selenium (ppm) & & & $0.020 \pm 0.008 \mathrm{a}$ \\
Before injection & $0.022 \pm 0.011 \mathrm{a}$ & $0.021 \pm 0.011 \mathrm{a}$ & $0.042 \pm 0.024 \mathrm{~b}$ \\
60d after injection & $0.022 \pm 0.009 \mathrm{a}$ & $0.027 \pm 0.011 \mathrm{a}$ & \\
Reproductive rate $(\%)$ & & & $94 \mathrm{a}$ \\
Fertility $^{1}$ & $92 \mathrm{a}$ & $95 \mathrm{a}$ & $105 \mathrm{a}$ \\
Prolificacy $^{2}$ & $107 \mathrm{a}$ & $101 \mathrm{a}$ & \\
\hline
\end{tabular}

Means with different letters are significantly different $(\mathrm{P}<0.05)$ from each other.

${ }^{1}$ Percentage of does kidding.

${ }^{2}$ Number of kids born of does kidding x 100 .

$\mathrm{Al}=$ control; $\mathrm{A} 2=0.06 \mathrm{mgSe}+0.8 \mathrm{IUvit} . \mathrm{E} / \mathrm{kgBW} ; \mathrm{A} 3=0.125 \mathrm{mgSe}+1.7 \mathrm{IUvit} . \mathrm{E} / \mathrm{kgBW}$.

Blood Se concentrations did not differ between SevitE and control group before injection, showing the Se deficient condition (Table 1). No difference was observed between $\mathrm{A}_{2}$ and control group 60 days pos-treatment $(\mathrm{P}<0.05)$, while significant differences $(\mathrm{P}<0.05,103 \%)$ for higher blood Se concentration were observed between A1 and A2 groups vs high Se injection A3 group. According to other studies (Morand-Fehr, 1981; Mba, 1982) the level of Se in all groups was under the critical level for ruminants, $0.1 \mathrm{ppm}$. Se levels in blood of both supplemented groups indicated that highest injection level was insufficient for the maintenance of Se status during pregnancy in does, nevertheless the low obtained levels did not affect reproductive indexes. Cohen et al. (1989) used similar doses in pregnant beef cows and noted that the plasma Se concentration did not differ between Se-vitE and control groups either before or after injection.

\section{Experiment 2}


There was a dramatic response to injected group with the highest level (B 4;0.31 mgSe/ $\mathrm{kgBW}$ ) as evidenced by the rising in blood Se concentrations above initial levels (Figure 1). This group reached a highest peak at third month $(0.11 \mathrm{ppm})$ after injection $(\mathrm{P}<0.05)$ and then started to decline after
100 days, reaching a value only slightly above groups B2 and B3 at 135 days. The B2 (21\%, $\mathrm{P}>0.05)$ and $\mathrm{B} 3(39 \%, \mathrm{P}<0.05)$ groups were marginally above those of control group B1 throughout the trial.

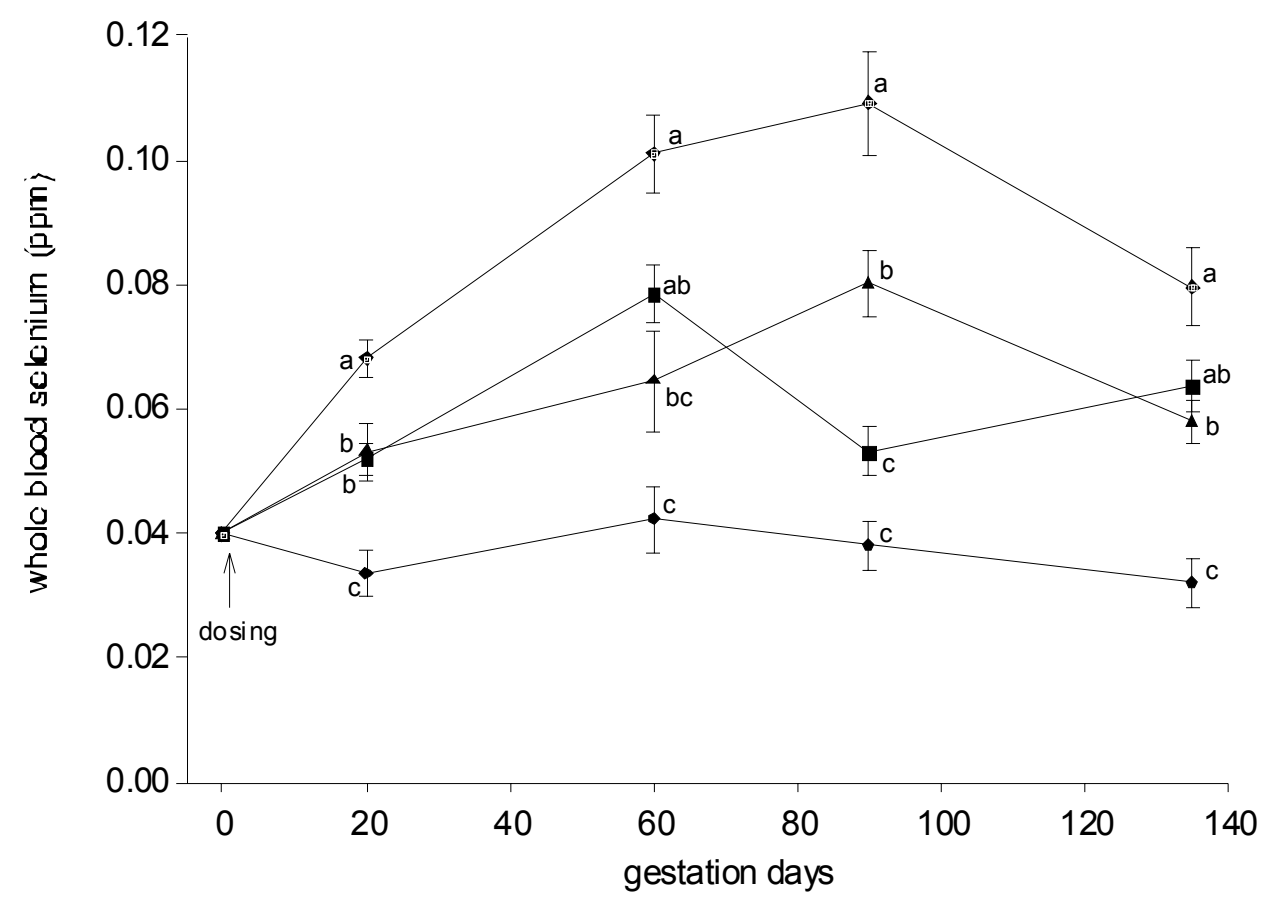

Figure 1. Changes in blood selenium levels due to injected Se and vit E in pregnant goats. Points represent means with their standard errors represented by vertical bars for 12 subjects per group $(\rightarrow-$ control, $\rightarrow$ $0.125 \mathrm{mgSe} / \mathrm{kgBW}, \longrightarrow 0.25 \mathrm{mgSe} / \mathrm{kgBW} \multimap-0.31 \mathrm{mgSe} / \mathrm{kgBW})$. Points at any given action gestation days with different letters were significantly different from each other $(\mathrm{P}<0.05)$.

In particular B2 does had an average blood Se concentration of $0.037 \mathrm{ppm}$ before Se injection $(0.125 \mathrm{mgSe}+1.7 \mathrm{UIvitE} / \mathrm{kgBW})$, and 60 days posttreatment increased to $0.078 \mathrm{ppm}$ blood Se concentration. This result is in disagreement with experiment 1 with similar dose, despite the fact that the Se source was obtained from the same laboratory lot. Maybe the large variation was associated with seasonal intake, requirement and excretion differences or distinct age gestational Se deposition in the fetuses (Langlands et al., 1982). It is possible that the marginal Se deficiency or vit $\mathrm{E}$ status in the goats may cause a greater movement of Se across the placenta to attend the fetal development requirements, again maternal exigencies or distress. Nevertheless, Shariff and Krishnamurti (1987) reported that Se transfer was directional across the placenta and the transfer rate was reduced in both directions under maternal Se deficiency and fetal Se metabolic utilization can remove the element from this interchange with a positive fetal balance.

The increase was greatest in the injected groups vs control group (Figure 1), suggesting Se mobilization from body stores to fetus in control does and a response to the Se injection in the treated goats. Decreased blood Se levels observed in B3 and B4 groups before 100 days, concurred with high fetal development at the end of gestation. Unfortunately, WMD was not studied in kids from goats injected with Se. Previous studies with sheep (Whanger et al., 1978) demonstrated the prevention of WMD by giving $5 \mathrm{mg}$ of Se (approximately 


\section{Ramírez-Bribiesca et al.}

$0.1 \mathrm{mgSe} / \mathrm{kgBW}$ ) at 90, 60 and 30 days prepartum, but it was discussed as a no practical method because the extra labor involved. Similarity, Cuesta et al. (1995) evaluated the effects of high-dose Se $(1.5 \mathrm{mgSe} / \mathrm{BW})$ injection to pregnant ewes and they observed that the treatment had no effect on serum Se concentrations of lambs or ewes. Surprisingly, this dose killed three does in the present experiment, soon after the $1.3 \mathrm{mgSe} / \mathrm{kgBW} \mathrm{Se}$ injection.

These results indicate that $\mathrm{Se}$ given does as injection $(0.31 \mathrm{mgSe}+4.2 \mathrm{UIvitE} / \mathrm{kgBW})$ is highly effective to maintain Se blood level in pregnant goats. Specifically, Se activity in blood is independent of dietary vit E (Siddons and Mills, 1981). Further research is necessary to determine if highest doses are necessary to prevent WMD in kids born from injected goats.

\section{Experiment 3}

At the start of the study blood Se levels did not differ significantly among the three groups of kids (Table 2). The Se concentration in blood increased rapidly in $\mathrm{C} 2$ and $\mathrm{C} 3,190 \%$ and $607 \%(\mathrm{P}<0.01)$, respectively. Previous studies have showed that $\mathrm{Se}$ treatments may have an impact on survival rates, in a single injected dosage from $0.16 \mathrm{mgSe} / \mathrm{kgBW}$ (Andrés et al., 1996), 0.4mgSe/kgBW (Milad et al., 2001 ) to $0.6 \mathrm{mgSe} / \mathrm{kgBW}$ (Allen et al., 1986) as sodium selenite in lambs. In this study both injected Se doses $(0.3 \mathrm{mgSe}+4.2 \mathrm{UIvitE} / \mathrm{kgBW}$ and
0.6mgSe+8.4UIvitE/kgBW) were considered able to maintain adequate blood Se levels in kids, this showed that, ignoring all mortality causes, Se-vitE injection was directly related to animals of survivor (Table 2). Control group, $\mathrm{C} 1$ demonstrated the highest percentage of mortality $(60 \%)$ vs both Segroups that scored almost equal percentage of deaths $(22 \%$ averaged $)$. This experiment corroborates the same result of previous study which has been conducted on the same region and showed a high mortality of kids involved with Se deficiency (Ramirez-Bribiesca et al., 2001a). Practically, Se supplementation enhances the level of Se and activity of GSH-Px, and may indirectly improve animal performance (Sobiech and Kuleta, 2002), possibly by strengthening the immunity of the animals (Milad et al., 2001). Larsen (1988) showed, in WMD lambs, that Se deficiency depressed lymphocyte response and reduced antibody production, but Vit E deficiency reveals no obvious common factor explaining the pathogenetic mechanisms that would account for such a wide range of pathological effects (Rice and Kennedy, 1988). Therefore, a single dose as $0.6 \mathrm{mgSe}+8.6 \mathrm{vitE} / \mathrm{kgBW}$ was not lethal to kids under these conditions, and there was no additional benefit in survival. It is reasonable to expect that the highest Se doses may result, occasionally, in the accidental induction of hyperselenosis; because the biological function of selenium shows a dual character, due the selenium content range between toxic and deficient concentration in animals is rather narrow.

Table 2. Selenium content (ppm) of blood samples and mortality rates in kids subcutaneously injected with selenium-vitamin E

\begin{tabular}{lccc}
\hline & $\mathrm{C} 1$ & $\mathrm{C} 2$ & $\mathrm{C} 3$ \\
\cline { 2 - 4 } & mean SD & mean SD & mean SD \\
\hline Before injection & $0.020 \pm 0.007 \mathrm{a}$ & $0.022 \pm 0.009 \mathrm{a}$ & $0.023 \pm 0.01 \mathrm{a}$ \\
& $(16)$ & $(16)$ & $(16)$ \\
20d after injection & $0.022 \pm 0.005 \mathrm{a}$ & $0.066 \pm 0.024 \mathrm{~b}$ & $0.153 \pm 0.065 \mathrm{c}$ \\
& $(9)$ & $(14)$ & $(13)$ \\
Mortality, $\%$ & $60 \mathrm{a}$ & $24 \mathrm{~b}$ & $20 \mathrm{~b}$ \\
dead:live & $24: 40$ & $19: 78$ & $16: 78$ \\
\hline
\end{tabular}

Number in parenthesis indicate number of observations.

Means with different superscripts are significantly different $(\mathrm{P}<0.05)$.

$\mathrm{Cl}=$ control; $\mathrm{C} 2=0.3 \mathrm{mgSe}+4.2 \mathrm{IUvitE} ; \mathrm{C} 3=0.6 \mathrm{mgSe}+8.4 \mathrm{IUvitE}$.

\section{CONCLUSIONS}


Interpretation of blood-Se results can change considerably depending on the level of Se injected. This study has shown that Se-vitE injection with $0.31 \mathrm{mgSe}+4.2$ UIvitE $/ \mathrm{kgBW}$ increased the blood Se concentration in pregnant goats. It also can be concluded that the treatment of WMD with a single dosage as sodium selenite-vitE mixture injected into kids $(0.3 \mathrm{mgSe}+4.2 \mathrm{UIvitE} / \mathrm{kgBW})$ is effective to enhance the survival of kids until weaning.

\section{REFERENCES}

ALLEN, J.G.; STEELE, P.; MASTERS, H.G. et al. A study of nutritional myopathy in weaner sheep. Aust.Vet. J., v.63, p.8-13, 1986.

ANDRÉS, S.; MAÑE, M.C.; SANCHEZ, J. et al. Changes in GSHPx and muscle enzyme activities in lambs with nutritional myodegeneration following a single treatment with sodium selenite. Small Rumin. Res., v.23, p.183-186, 1996.

ANKE, M.; ANGELOW, L.; ANGELOW, L. et al. Effect of selenium deficiency upon reproduction and milk production of goats. In: PROCEEDINGS MACRO- AND TRACE ELEMENT SEMINAR, 1987. University Leipzing-Jena, Germany, 1987. P.440-447.

COHEN, R.D.H.; KING, B.D.; GUENTHER, C. et al. Effect of selenium/vitamin E supplementation of pregnant beef cows on cow and calf production. Proc. West. Sec. Am. Soc. Anim. Sci., v.40, p.370372, 1989.

CUESTA, P.A.; MCDOWELL, L.R.; KUNKLE, W.E. et al. Effects of high-dose prepartum injections of Se and vitamin E on milk and serum concentrations in ewes. Small Rumin. Res., v.18, p.99-103, 1995.

GABRYSZUK, M.; KLEWIEC, J. Effect of injecting 2- and 3-year-old ewes with selenium and selenium-vitamin E on reproduction and rearing of lambs. Small Rumin. Res., v.43, p.127-132, 2002.

LANGLANDS, J.P.; BOWLES, J.E.; DONALD, G.E. et al. Deposition of cooper, manganese, selenium and zinc in the ovine foetus and associated tissues. Aust. J. Agric. Res., v.33, p.591601. 1982.

LARSEN, H.J. Influence of selenium on antibody production in sheep. Res. Vet. Sci., v.45, p.4-10, 1988.
MBA, A.U. Mineral nutrition of goats in Nigeria. In: PROCEEDING INTERNATIONAL CONFERENCE, GOAT PRODUCTION AND DISEASE, 3. Dairy Goat Journal Publishing Co. Scottsdale, AZ. USA, 1982. P.109-112.

MCDOWELL, L.R.; WILLIAMS, S.N.; HIDIROGLOU, N. et al. Vitamin E supplementation for the ruminants. Anim. Feed Sci. Technol., v.60, p.273-296, 1996.

MESCHY, F. Recent progress in the assessment of mineral requirements of goats. Livest. Prod. Sci., v.64, p.9-14, 2000.

MILAD, K.; RÁCZ, O.; SIPULOVÁ, A. et al. Effect of vitamin $\mathrm{E}$ and selenium on blood glutathione peroxidase activity and some immunological parameters in sheep. Vet. Med. Czech., v.46, p.1-5, 2001.

MORAND-FEHR, P. Nutrition and feeding of goat: application to temperature climatic condition. In: GALL,... (Ed.). Goat production. London: Academic, 1981. P.193-232.

PASTRANA, R.; MCDOWELL, L.R.; CONRAD, J.H. et al. Mineral status of sheep in the Paramo region of Colombia. II. Trace minerals. Small Rumin. Res., v.5, p.23-34, 1991.

RAMÍREZ-BRIBIESCA, J.E.; TÓRTORA, J.L.; HERNÁNDEZ, L.M. et al. Main causes of mortalities in dairy goat kids from the Mexican plateau. Small Rumin. Res., v.41, p.77-80, 2001a.

RAMÍREZ-BRIBIESCA, J.E.; TÓRTORA, J.L.; HUERTA, M. et al. Diagnosis of selenium status in grazing dairy goats on the Mexican plateau. Small Rumin. Res., v.41, p.81-85, $2001 \mathrm{~b}$.

RICE, D.; KENNEDY, S. Vitamin E: Function and effects of deficiency. Br. Vet. J., v.144, p.482-496. 1988.

SHARIFF, M.A.; KRISHNAMURTI, C.R. Effect of dietary Se on in utero placental Se transfer in ewes. Can. J. Anim. Sci., v.67, p.1207, 1987.

SIDDONS, R.C.; MILLS, C.F. Glutathione peroxidase activity and erythrocyte stability in calves differing in selenium and vitamin E status. Br. J. Nutr., v.46, p.345-349, 1981.

SOBIECH, P.; KULETA, Z. Usefulness of some biochemical indicators in detection of early stages of nutritional muscular dystrophy in lambs. Small Rumin. Res., v.45, p.209-215, 2002. 


\section{Ramírez-Bribiesca et al.}

STEEL, R.G.D.; TORRIE J.H. Principles and procedures of statistical: A biometrical approach. 2.ed. New York: McGraw-Hill Book, 1980.

USER'S guide: statistics. Version 6, 4.ed. Cary, NC: SAS, 1990. 1028p.

WHANGER, P.D.; WESWING, P.H.; SCHMITZ, J.A. et al. Effects of various methods of selenium administration on white muscle disease, glutathione peroxidase and plasma enzyme activities in sheep. J. Anim. Sci., v.47, p.11571166, 1978.

WHETTER, P. A.; ULLREY, D.E. Improved fluorometric method for determining selenium. $J$. Assoc. Off. Anal. Chem., v.61, p.927-930, 1978. 